\title{
Water relations and hydraulic characteristics of three woody species co-occurring in the same habitat
}

\author{
Andrea NARDINI ${ }^{a *}$, Sebastiano SALleO $^{\mathrm{a}}$, Patrizia TRIFILÒ ${ }^{\mathrm{a}}$ and Maria Assunta Lo Gullo ${ }^{\mathrm{b}}$

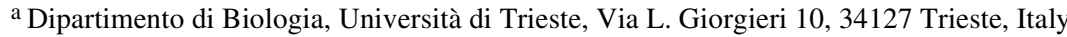 \\ b Dipartimento di Scienze Botaniche, Università di Messina, Salita Sperone 31, 98166 Messina S. Agata, Italy
}

(Received 30 April 2002; accepted 22 July 2002)

\begin{abstract}
Three woody species typically encroaching the Karstic region of Trieste (Northeastern Italy) i.e. Cotinus coggygria L., Prunus mahaleb L. and Fraxinus ornus L., have been measured for diurnal and seasonal time courses of leaf conductance to water vapour, transpiration and water potential $\left(\Psi_{\mathrm{L}}\right)$, as well as whole-plant, shoot and root hydraulic resistance $\left(\mathrm{R}_{\text {plant }}, \mathrm{R}_{\text {shoot }}\right.$ and $\mathrm{R}_{\text {root}}$, respectively) in view of investigating the impact of plant hydraulics on water stress resistance. F. ornus suffered the highest $\Psi_{\mathrm{L}}$ drop in July and September due to the high $R_{\text {plant }}$ measured in this species. Positive significant relations were found of $R_{\text {plant }}$ and $\Psi_{L}$ to $R_{\text {root }}$ in all three species studied, thus suggesting that root hydraulics is a major determinant of plant hydraulics and water stress resistance. The increasing $R_{\text {root }}\left(\right.$ and $\left.R_{\text {plant }}\right)$ from C. coggygria to $P$. mahaleb to $F$. ornus provided a possible explanation for the typical temporal sequence of expansion of the three species into degraded areas.
\end{abstract}

hydraulic architecture / water relations / Cotinus coggygria / Prunus mahaleb / Fraxinus ornus

Resumé - Relations hydriques et caractéristiques hydrauliques de trois espèces ligneuses présentes dans le même habitat. Trois espèces ligneuses, typiquement en cours d'extension dans la région Karstique de Trieste (Italie du nord) i.e. Cotinus coggygria L., Prunus mahaleb L. and Fraxinus ornus L., ont été suivies aux échelles journalières et saisonnières en termes de conductance foliaire pour la vapeur d'eau, de transpiration et de potentiel hydrique $\left(\Psi_{\mathrm{L}}\right)$, ainsi que de résistance hydraulique totale, tige et racinaire $\left(\mathrm{R}_{\text {plant }}, \mathrm{R}_{\text {shoot }}\right.$ and $\mathrm{R}_{\text {root }}$, respectivement $)$ dans l'objectif d'analyser l'impact des paramètres hydrauliques des plantes sur leur résistance au stress hydrique. $F$. ornus a montré la plus grande chute de $\Psi_{\mathrm{L}}$ en Juillet et Septembre en raison de la grande valeur de $\mathrm{R}_{\text {plant }}$ mesurée chez cette espèce. Des relations positives et significatives ont été trouvées entre $\mathrm{R}_{\text {plant }}, \Psi_{\mathrm{L}}$ et $\mathrm{R}_{\text {root }}$ pour les trois espèces étudiées, ce qui suggère que les propriétés hydrauliques des racines sont un déterminant majeur des propriétés hydrauliques de la plante et de leur résistance au stress hydrique. Les valeurs croissantes de $\mathrm{R}_{\text {root }}$ (et $\mathrm{R}_{\text {plant }}$ ) de $C$. coggygria à $P$. mahaleb et $F$. ornus fournissent une explication possible pour la séquence temporelle d'expansion de ces trois espèces dans les zones dégradées.

architecture hydraulique / relations hydriques / Cotinus coggygria / Prunus mahaleb / Fraxinus ornus

\section{INTRODUCTION}

The concept of "hydraulic architecture" of plants was first introduced by M. Zimmermann $[43,46]$ in view of relating the structure and physical properties of the water conducting system to plant water balance and adaptation to the environment. In this framework, the partitioning of the hydraulic resistances (R) along the plant body and their seasonal changes are of particular interest and, in fact, Zimmermann and co-workers have discussed extensively the possible evolutive and adaptive significance of changes in the hydraulic conductance $(K=1 / R)$ of stems and leaves of several tree species [45, 46]. During the last two decades, our knowledge of the hydraulic architecture of plants has been enriched with accurate measurements of the hydraulic resistance of the root $\left(R_{\text {root }}\right)$ whose dominant component (by
85 to $95 \%$ ) has revealed to reside in the radial pathway between the soil and the root stele $[16,36]$. In turn, the overall shoot resistance $\left(\mathrm{R}_{\text {shoot }}\right)$ has been reported to be dominantly located in the leaf blade $\left(\mathrm{R}_{\text {leaf }}\right)$ i.e. leaves would account for 50 to $90 \%$ of the measured $R_{\text {shoot }}[19,21,40]$. On the basis of the above, a plant might be viewed as consisting of two opposite poles i.e. the leaf and the radial soil-to-root stele pathway, both characterized by high R's and connected to one another by a low-R pathway (the xylem). This last water path, however, can increase its own $\mathrm{R}$ by a factor of two or more due to cavitation [41]. A convincing body of evidence, in fact, has accumulated showing that xylem cavitation takes place in conduits whenever tensions in them exceed critical thresholds so that gaseous microbubbles are sucked into conduits leading to their embolism and blockage [34, 41, 44]. Some of the several species studied for cavitation so far, however, have 
shown to recover from xylem embolism at least partly, as transpiration declines and even in presence of active transpiration [3] in a matter of minutes [8, 39] or hours [47].

According to the Ohm's law hydraulic analogue, the hydraulic resistance of a plant $\left(\mathrm{R}_{\text {plant }}\right)$ is positively related to the driving force for the flow corresponding to the water potential $(\Psi)$ difference between the soil and leaf $\left(\Psi_{\text {soil }}-\Psi_{L}\right)$ i.e.:

$$
\mathrm{R}_{\text {plant }}=\left(\Psi_{\text {soil }}-\Psi_{\mathrm{L}}\right) / \mathrm{F},
$$

where $\mathrm{F}$ is the flow through the plant. Because the root and the shoot are serial components in a plant,

$$
\mathrm{R}_{\text {plant }}=\mathrm{R}_{\text {root }}+\mathrm{R}_{\text {shoot }} \text {. }
$$

Under sufficient water availability, the hydraulic resistance of the root is 50 to $60 \%$ of that of the whole plant [37] i.e.:

$$
\mathrm{R}_{\text {root }} \cong \mathrm{R}_{\text {shoot }} \text {. }
$$

During water shortage conditions, however, as well as under freeze or salinity stress, $R_{\text {plant }}$ can increase significantly in both its components $\left(\mathrm{R}_{\text {root }}\right.$ and/or $\left.\mathrm{R}_{\text {shoot }},[4,14,16,25]\right)$. In particular, $\mathrm{R}_{\text {root }}$ may increase due to root cavitation $[11,33]$ and/or to the new formation of a multi-layer suberized endoderm-like tissue that hydraulically isolates the stele from the cortex $[5,12,16,23]$. In turn, $\mathrm{R}_{\text {shoot }}$ can be enhanced by stem and leaf vein cavitation [22, 28] and stomatal closure [30, 32]. Sperry et al. [31] have developed a model showing that plant water use is mainly limited by the efficiency of the xylem and only to a lesser extent by the rhizosphere. Nardini et al. $[17,20]$, on the other hand, reported that the decrease in leaf conductance to water vapour $\left(\mathrm{g}_{\mathrm{L}}\right)$ and water potential $\left(\Psi_{\mathrm{L}}\right)$ recorded in Quercus species during Sicilian summers were paralleled by opposite changes in $R_{\text {root }}$. Now, the question arises whether the major contribution to the increase in $R_{\text {plant }}$ under stress conditions is due to $R_{\text {root }}$ or $R_{\text {shoot }}$. Answering this question has both theoretical and practical interest because the recovery of the hydraulic efficiency of the shoot i.e. xylem refilling and stomatal re-opening, is likely to require less metabolic investment by the plant than that of the root at least in the case new roots have to be produced to substitute for those no longer in hydraulic continuity with the soil $[5,12]$.

In view of investigating possible relationships existing between changes in hydraulic resistance of plants and their adaptation to the environment, in the present study we report daily and seasonal measurements of water relation parameters as well as of root and shoot hydraulic resistance in three fieldgrowing species co-occurring in the same habitat i.e. Cotinus coggygria L. (Wig tree), Prunus mahaleb L. (Mahaleb cherry) and Fraxinus ornus L. (Manna ash). These species are dominant components of the vegetation developing during the natural encroachment of abandoned rural areas in the Karstic region (Friuli-Venezia Giulia, Northeastern Italy). The Karstic areas are characterized by high soil drainage [24] so that even in presence of sufficient annual rainfall, plants may suffer summer (and winter) water stress [20]. The dynamic sequence of expansion of the three species above into the area sees C. coggygria settling first, followed by $P$. mahaleb and some years later, by $F$. ornus $[9,10,24]$. A previous study of some of us [17] had shown that the co-occurrence of two
Mediterranean Quercus species (Q. suber L. and Q. cerris L.) in Sicily could be explained in terms of their complementary changes in $\mathrm{R}_{\text {root }}$ through the year that allowed the peaks of their water demand to be reached in different periods of the year. Therefore, a second objective of our study was to check whether the co-occurrence of $C$. coggygria, $P$. mahaleb and $F$. ornus might be explained on the basis of different hydraulics and adaptive strategies.

\section{MATERIALS AND METHODS}

\subsection{The study site}

The study site was located near the village of Basovizza in the Karstic area of Trieste at an altitude of about $300 \mathrm{~m}$. The soil in this area is a poorly developed brown soil with rather low water retention $[1,24]$ and the typical climate has been defined as a pre-Alpine continental climate. Mean rainfall is about $1150 \mathrm{~mm}$ with a maximum in autumn and a minimum in winter (between January and March). Winter temperatures often fall below $0{ }^{\circ} \mathrm{C}$ and in the coldest month (January) the mean of the daily minima is, on average, $2.9{ }^{\circ} \mathrm{C}$ (data from the Oceanography and Meteorology Section, Dept. of Earth Sciences, University of Trieste). The vegetation in the study site consisted of well developed shrubs of $C$. coggygria mixed with $P$. mahaleb and $F$. ornus trees as dominant species. Other cooccurring woody species were: Crataegus monogyna, Rosa canina, Q. pubescens, Acer monspessulanum, Juniperus communis and Pinus nigra ([24] and personal observations).

\subsection{Measurements of plant water status and hydraulics}

The diurnal time course of leaf conductance to water vapour $\left(\mathrm{g}_{\mathrm{L}}\right)$, transpiration rate $\left(\mathrm{E}_{\mathrm{L}}\right)$ and water potential $\left(\Psi_{\mathrm{L}}\right)$ was recorded every $60 \mathrm{~min}$ between $0630 \mathrm{~h}$ (pre-dawn) and $1830 \mathrm{~h}$ solar time, in selected sunny days of May (23 to 25), July (26 to 28) and September (12 to 15) 2000. These months were selected for measurements because previous studies $[18,20]$ had shown that although the spring is usually rainy in Venezia Giulia, plants suffer some loss of hydraulic conductance due to winter embolism while July is the warmest month and September is usually preceded by a dry period (August) and coincides with the beginning of processes leading to leaf senescence. Measurements were performed on three adult individuals of each species with an estimated age of 15-20 years. The same individuals were measured for the above variables in May, July and September. Samples for measuring leaf water status and gas exchange (see below) were sun leaves collected from the S-exposed part of the crown.

Leaf conductance to water vapour and transpiration rate were measured of at least 15 leaves per species and per daytime using a portable steady-state porometer (LI1600, LiCor Inc., Lincoln, NE, USA). Air temperature ( $\left.\mathrm{T}_{\text {air }}\right)$, relative humidity (RH) and photosynthetically active radiation (PAR) were also recorded using the porometer cuvette, at about $1 \mathrm{~m}$ from the $\mathrm{S}$-exposed part of the crown. Leaf water potential $\left(\Psi_{\mathrm{L}}\right)$ was measured of six to ten leaves per species and per daytime using a portable pressure chamber (3005 Plant Water Status Console, Soilmoisture Equipment Corp., Goleta, CA, USA) with sheets of wet filter paper inside the chamber to minimize water loss during measurements.

In order to estimate seasonal changes in $\Psi_{\mathrm{L}}$ at the turgor loss point ( $\left.\Psi_{\mathrm{TLP}}\right)$, pressure-volume curves $[27,38]$ of four to five leaves per species and per study period were measured. The turgor loss point served as a reference point for estimating the residual turgor of leaves 
when reaching the minimum diurnal $\Psi_{\mathrm{L}}$ [13]. So as to quantify the overall diurnal drop in $\Psi_{\mathrm{L}}$, the integral of $\Psi_{\mathrm{L}}$ was calculated between two reference daytimes i.e. predawn and sunset when $\Psi_{\mathrm{L}}$ is least negative. We named this variable "Water Stress Index" or WSI [42]. In other words:

$$
\mathrm{WSI}=\int_{t 0}^{t x} \Psi_{\mathrm{L}}(\mathrm{t}) \mathrm{dt},
$$

where $t_{0}$ and $t_{x}$ are predawn and sunset times, respectively and $d t$ is the time interval during which $\Psi_{\mathrm{L}}$ was measured. This $\Psi_{\mathrm{L}}$ expression was first proposed by Mishio and Yokoi [15] and has proved to be a more reliable indicator of the amount of water stress suffered by plants [42] with respect to other common variables used to the same purpose like minimum $\Psi_{\mathrm{L}}$ or the difference between pre-dawn and minimum diurnal $\Psi_{\mathrm{L}}$.

An estimate of the seasonal changes in the hydraulic resistance $(\mathrm{R})$ of plants $\left(R_{\text {plant }}\right)$ as well as of that of the root system $\left(R_{\text {root }}\right)$ and shoot $\left(\mathrm{R}_{\text {shoot }}\right)$ was obtained using the "evaporative flux" method (EF) which is based upon the Ohm's law hydraulic analogue i.e.:

$$
\begin{aligned}
\mathrm{R}_{\text {plant }} & =\left(\Psi_{\mathrm{pd}}-\Psi_{\text {min }}\right) / \mathrm{E}_{\mathrm{L}}, \\
\mathrm{R}_{\text {root }} & =\left(\Psi_{\mathrm{pd}}-\Psi_{\mathrm{X}}\right) / \mathrm{E}_{\mathrm{L}}, \\
\mathrm{R}_{\text {shoot }} & =\left(\Psi_{\mathrm{X}}-\Psi_{\min }\right) / \mathrm{E}_{\mathrm{L}},
\end{aligned}
$$

where $\Psi_{\text {pd }}$ is pre-dawn $\Psi_{\mathrm{L}}$ which is assumed to equilibrate to soil water potential i.e. $\Psi_{\text {soil }} \approx \Psi_{\mathrm{pd}}[26], \Psi_{\min }$ is the minimum diurnal $\Psi_{\mathrm{L}}$ as measured at midday and $\mathrm{E}_{\mathrm{L}}$ is the midday transpiration rate. The term $\Psi_{\mathrm{X}}$ represents the water potential of xylem at the trunk base. This was estimated by covering four to five leaves growing near the base of plants with plastic film and aluminum foil before sunrise. Under these conditions, leaf water potential is generally agreed to equilibrate to that of the adjacent xylem [26]. The covered leaves were collected at midday and measured for $\Psi_{\mathrm{L}}$. Midday values of $\Psi_{\mathrm{L}}$, $\Psi_{\mathrm{X}}$ and $\mathrm{E}_{\mathrm{L}}$ were preferred because at this daytime plants are likely to have transpired all their stored water so that steady-state water flow conditions are likely to establish.

In other words, because $\Psi_{\text {pd }}$ is assumed to equilibrate with $\Psi_{\text {soil }}$ (which is the case for not really arid soils), $\left(\Psi_{\mathrm{pd}}-\Psi_{\min }\right)$ in equation 5 would represent the water potential difference driving the flow from the soil to the leaf (at midday). In turn, $\left(\Psi_{\mathrm{pd}}-\Psi_{\mathrm{x}}\right)$ in equation 6 would be the driving force for the flow from the soil to the trunk base and $\left(\Psi_{\mathrm{x}}-\Psi_{\min }\right)$ in equation 7 would be that between the trunk base and the leaf.

We are aware that in many cases $\Psi_{\text {pd }}$ may not equilibrate with $\Psi_{\text {soil }}$ [26], so that measuring $\Psi_{\text {soil }}$, directly would be more correct. However, Karstic soils are characterized by deep fissures in the rocky subsoil into which roots may penetrate, so that measuring the water potential of a soil sample is likely to provide false information of the water potential actually experienced by plant roots. In these cases, estimating $\Psi_{\text {soil }}$ on the basis of $\Psi_{\text {pd }}$ is preferable and $\Psi_{\text {pd }}$ represents the maximum (i.e., least negative) water potential plants can reach under given conditions.

\section{RESULTS}

The annual time course of air temperatures $\left(\mathrm{T}_{\text {air }}\right)$ and precipitation (Fig. 1, data from the Oceanography and Meteorological Section, University of Trieste for the year 2000, recorded about $1 \mathrm{Km}$ from the study site) was characterized by a typically arid and cold winter (mean $\mathrm{T}_{\text {air }}$ dropped to $-6{ }^{\circ} \mathrm{C}$ and only about $10 \%$ of annual precipitation was recorded between January and March). Two peaks of

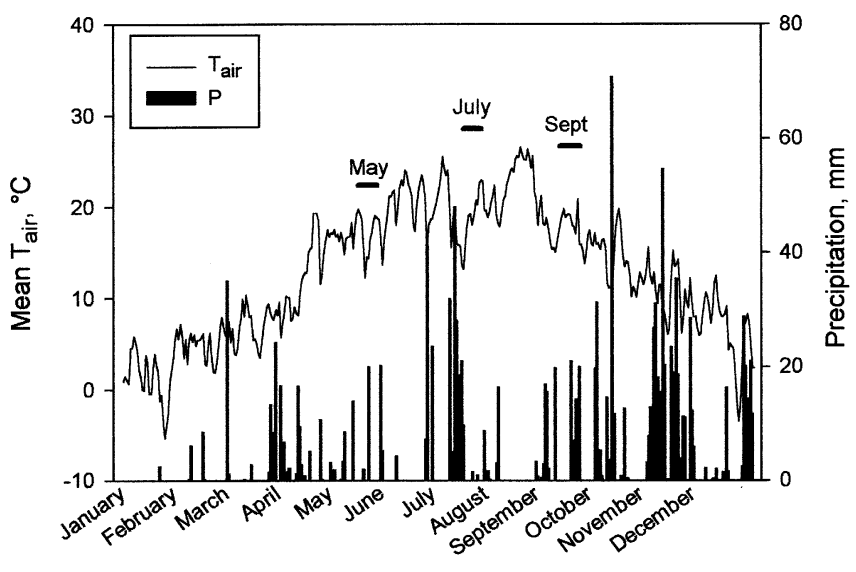

Figure 1. Annual time course of mean air temperatures (upper curve) and precipitation (vertical bars) during the year 2000. The study periods were May, July and September and are indicated by horizontal bars.

precipitation were recorded in the course of year 2000, one of which occurred in July i.e. about one month later with respect to the mean of the last 30 years, and a second one, in November. Therefore, measurements of plant water status in July were made during a warm, wet period. In September, on the contrary, plants received scarce rainfall (and in August as well, Fig. 1) while air temperatures were still high (mean $\mathrm{T}_{\text {air }}$ was over $20^{\circ} \mathrm{C}$ ).

\subsection{Changes in plant water status}

The diurnal time courses of $\mathrm{g}_{\mathrm{L}}, \mathrm{E}_{\mathrm{L}}$ and $\Psi_{\mathrm{L}}$ as measured in the three species under study are reported in Figures 2, 3 and 4. Changes in $g_{\mathrm{L}}$ and $\mathrm{E}_{\mathrm{L}}$ as recorded in May, July and September were qualitatively similar in $C$. coggygria, $P$. mahaleb and $F$. ornus, the largest midday $\mathrm{g}_{\mathrm{L}}$ and $\mathrm{E}_{\mathrm{L}}$ being recorded in July ( $g_{\mathrm{L}}$ was 200 to $250 \mathrm{mmol} \mathrm{m}^{-2} \mathrm{~s}^{-1}$ ) and the lowest values being recorded in September $\left(\mathrm{g}_{\mathrm{L}}\right.$ was 75 to $100 \mathrm{mmol} \mathrm{m}^{-2} \mathrm{~s}^{-1}$ ). In all the three species and year periods studied, $\mathrm{E}_{\mathrm{L}}$ paralleled $\mathrm{g}_{\mathrm{L}}$. The three species differed, however, for their $\Psi_{\mathrm{L}}$ time courses. In $C$. coggygria, $\Psi_{\mathrm{L}}$ decreased progressively from May to September (Fig. 2) both in terms of $\Psi_{\text {min }}$ (from -1.0 to $-2.0 \mathrm{MPa}$ ) and in terms of $\Psi_{\text {pd }}$ (from -0.4 to $-1.1 \mathrm{MPa})$. It can be noted, however, that the $\Psi_{\mathrm{L}}$ time course recorded in May was, in this species, not very different from that recorded in July.

The seasonal decrease in $\Psi_{\mathrm{L}}$ was slightly smaller in $P$. mahaleb with respect to that measured in $C$. coggygria in that $\Psi_{\text {min }}$ decreased only from -1.2 to $-1.8 \mathrm{MPa}$ from May to September and $\Psi_{\mathrm{pd}}$ from -0.4 to $-0.6 \mathrm{MPa}$ in the same time interval. It has to be noted that the lowest diurnal $\Psi_{\mathrm{L}}$ values recorded in July in this species recovered promptly while they were maintained for several hours in September (from 0930 to 1600 h, Fig. 3) and recovered only during the night.

The diurnal time course of $\Psi_{\mathrm{L}}$ in $F$. ornus was quantitatively different from that recorded in the other two 


\section{Cotinus coggygria $\mathrm{L}$.}

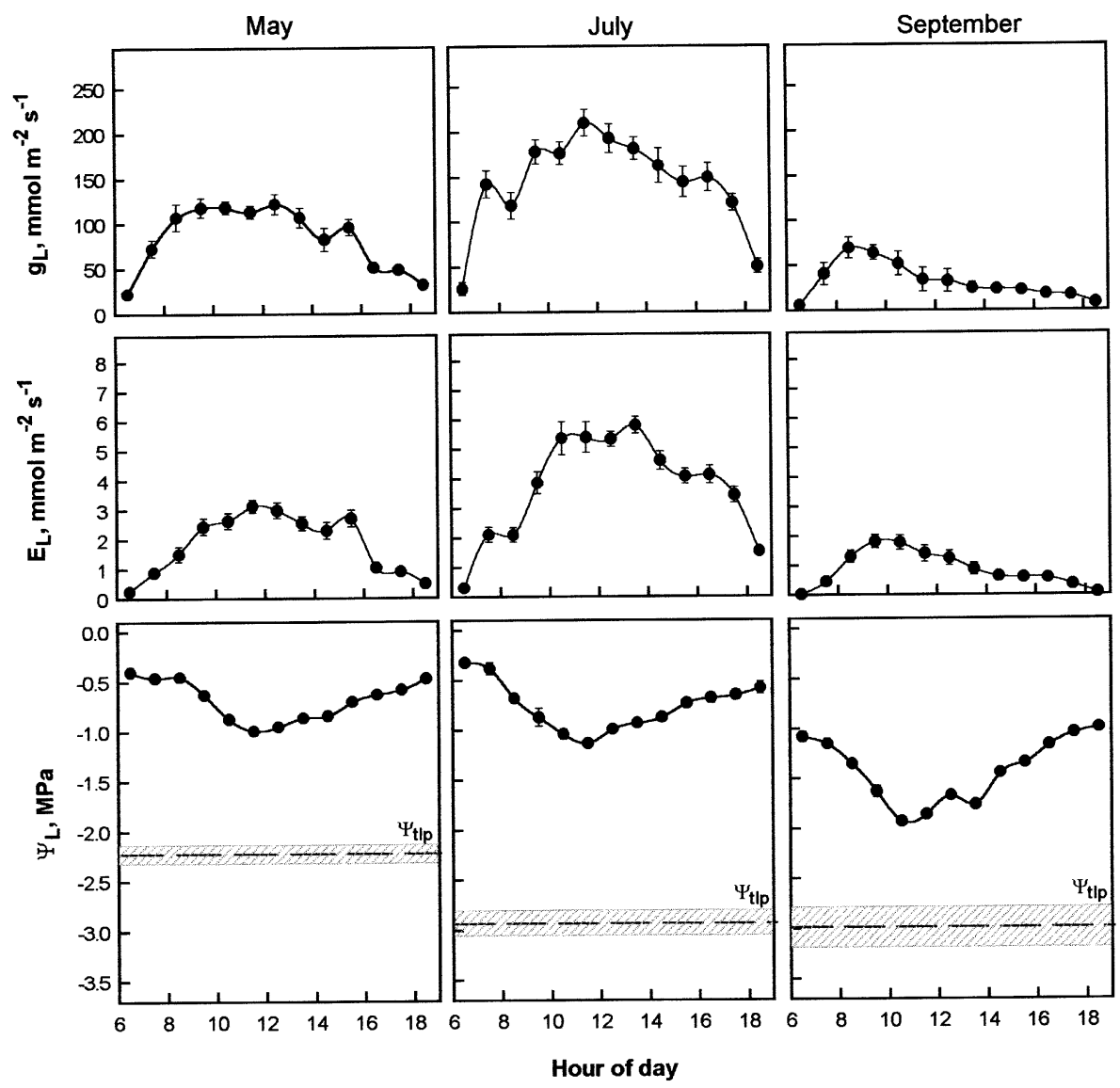

Figure 2. Diurnal time courses of leaf conductance to water vapour $\left(\mathrm{g}_{\mathrm{L}}\right)$, transpiration $\left(\mathrm{E}_{\mathrm{L}}\right)$ and water potential $\left(\Psi_{\mathrm{L}}\right)$ as measured in Cotinus coggygria L. fieldgrowing plants. Vertical bars are SD of the mean. The mean leaf water potential at the turgor loss point $\left(\Psi_{\text {tlp }}\right)$ is also reported $\pm \mathrm{SD}$ (dashed area). species (Fig. 4). The strong reduction in $g_{L}$ and $E_{L}$ (by a factor of over three) recorded in September with respect to values recorded in July, was paralleled by $\Psi_{\mathrm{L}}$ dropping to $-3.5 \mathrm{MPa}$ and reaching the turgor loss point $\left(\Psi_{\text {tlp }}\right)$. Such a low $\Psi_{\mathrm{L}}$ level was more or less maintained during the warmest hours of the day i.e. between 1000 and $1600 \mathrm{~h}$ but it recovered in the afternoon. In the same month, also $\Psi_{\mathrm{pd}}$ was found to drop substantially i.e. it became threefold more negative than that recorded in May and July. Although July 2000 was characterized by unusually high precipitation (Fig. 1), $\Psi_{\mathrm{L}}$ of $F$. ornus dropped to $-2.3 \mathrm{MPa}$, a level approaching the turgor loss point ( $\Psi_{\text {tlp }}$ was $\left.-2.5 \mathrm{MPa}\right)$.

Figures 2, 3 and 4 show that the minimum diurnal $\Psi_{\mathrm{L}}$ values were either promptly recovered or maintained during the warmest hours of the day. In this last case, the total "pressure" acting on plant metabolism due to decreased water status can be better estimated in terms of WSI that takes into proper account the duration of the minimum $\Psi_{\mathrm{L}}$ levels and also the extent to which $\Psi_{\text {pd }}$ actually decreased. WSI as calculated for $C$. coggygria and $P$. mahaleb was of the order of 8 to $9 \mathrm{MPa} h$ for the former species and 12 to $14 \mathrm{MPa} h$ for the latter in May and July, but increased significantly in
September when WSI increased twofold in $C$. coggygria i.e. from about 9 to $18 \mathrm{MPa}$ h (Fig. 5). In P. mahaleb, meanwhile, the increase in WSI from the spring to late summer was of the order of only about $38 \%$ (from 13 to $18 \mathrm{MPa} \mathrm{h}$ ). The largest changes in WSI were recorded in F. ornus, however, where the integral of $\Psi_{\mathrm{L}}$ between predawn and sunset increased significantly in July, already (from about 12 to $18 \mathrm{MPa}$ h, i.e., by $50 \%$ ) and much more in September when it was found to be of the order of about $35 \mathrm{MPa}$ h i.e. three times higher than that calculated in May.

\subsection{Partitioning of hydraulic resistances}

Seasonal changes in $\mathrm{R}_{\text {plant }}$ and its components $\left(\mathrm{R}_{\text {root }}\right.$ and $\mathrm{R}_{\text {shoot }}$ ) are reported in Figure 6 . The whole plant hydraulic resistance $\left(R_{\text {plant }}\right.$, white columns) changed in a qualitatively similar way in the three species under study. In fact, $\mathrm{R}_{\text {plant }}$ was found to decrease in July with respect to May but to increase substantially in September. In the spring, the lowest $R_{\text {plant }}$ was recorded in C. coggygria (about $1.0 \times 10^{4} \mathrm{MPa} \mathrm{s} \mathrm{m} \mathrm{kg}^{-1}$ ) and the highest one, in $F$. ornus (about double). $\mathrm{R}_{\text {plant }}$ as recorded in July was in every case, of the order of 20 to $30 \%$ less than 


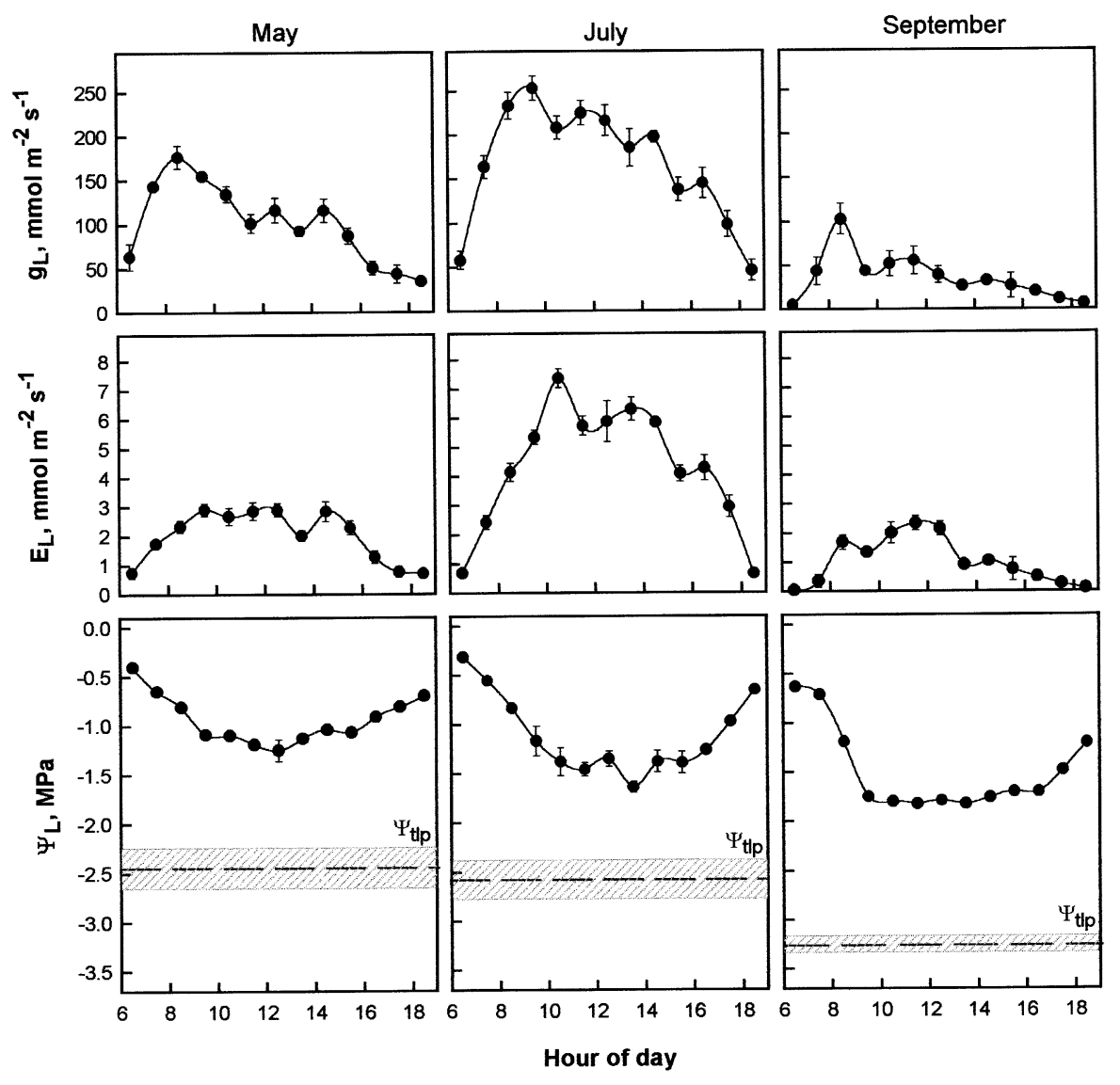

Figure 3. Diurnal time courses of leaf conductance to water vapour $\left(\mathrm{g}_{\mathrm{L}}\right)$, transpiration $\left(\mathrm{E}_{\mathrm{L}}\right)$ and water potential $\left(\Psi_{\mathrm{L}}\right)$ as measured in Prunus mahaleb L. field-growing plants. Vertical bars are $\mathrm{SD}$ of the mean. The mean leaf water potential at the turgor loss point $\left(\Psi_{\text {tlp }}\right)$ is also reported $\pm \mathrm{SD}$ (dashed area). that measured in May. In September, $\mathrm{R}_{\text {plant }}$ was about twice as much as that measured in the spring in $C$. coggygria and $P$. mahaleb and 2.4 times more in $F$. ornus. In turn, $\mathrm{R}_{\text {shoot }}$ (dashed columns, Fig. 6) was significantly larger than $\mathrm{R}_{\text {root }}$ (black columns) in May, in all species studied. In July, the relative contribution of $R_{\text {shoot }}$ to $R_{\text {plant }}$ became smaller so that $\mathrm{R}_{\text {shoot }}$ became approximately equal to $\mathrm{R}_{\text {root }}$ in $C$. coggygria and $F$. ornus (about 0.25 and $0.8 \times 10^{4} \mathrm{MPa} \mathrm{s} \mathrm{m} \mathrm{kg}^{-1}$, respectively) while $\mathrm{R}_{\text {shoot }}$ was only about one third of $\mathrm{R}_{\text {root }}$ in P. mahaleb $\left(\mathrm{R}_{\text {shoot }}\right.$ and $\mathrm{R}_{\text {root }}$ were about 0.2 and $0.7 \times 10^{4} \mathrm{MPa}$ $\mathrm{s} \mathrm{\textrm {m } ^ { 2 }} \mathrm{kg}^{-1}$, respectively). In September, $\mathrm{R}_{\text {shoot }}$ contributed rather little to $\mathrm{R}_{\text {plant }}$ (only $10 \%$ in P. mahaleb and about one third in C. coggygria and F. ornus).

The impact of $\mathrm{R}_{\text {root }}$ on $\mathrm{R}_{\text {plant }}$ is described in Figure 7 where all $R_{\text {root }}$ values recorded in the three species and year periods under study were plotted versus the corresponding $R_{\text {plant }}$ values. The two variables resulted to be positively and linearly related to one another with a correlation coefficient as high as 0.91 and with a significance of $P<0.0001$. The overall resistance of the root system $\left(\mathrm{R}_{\text {root }}\right)$ appeared to be also linearly and positively related to WSI (Fig. 8). The overall diurnal drop in $\Psi_{\mathrm{L}}$ (WSI) increased in response to the increase in $\mathrm{R}_{\text {root }}$, in all species studied, with a coefficient of about 0.80 and a significance of $P<0.01$.

\section{DISCUSSION}

The three species under study did not differ much for seasonal patterns of $\mathrm{g}_{\mathrm{L}}, \mathrm{E}_{\mathrm{L}}$ or RWC (Figs. 2, 3 and 4). At least two significant differences among species, however, emerged in terms of seasonal changes in the $\Psi_{\mathrm{L}}$ time course. Primarily, diurnal $\Psi_{\mathrm{L}}$ s recorded in $C$. coggygria and $P$. mahaleb did not approach their respective leaf turgor loss points in any of the periods studied i.e., leaves of the two species maintained their turgor even through the summer period. Leaves of $F$. ornus, meanwhile, not only showed $\Psi_{\mathrm{L}}$ s dropping very near to their $\Psi_{\text {tlp }}$ in July already but reached $\Psi_{\text {tlp }}$ in September when leaf turgor was lost for several hours during the day (Fig. 4), in spite of consistent stomatal closure i.e., at low $\mathrm{g}_{\mathrm{L}}$. Secondly, the environmental pressure acting on plants, expressed here as the overall diurnal drop in $\Psi_{\mathrm{L}}$ (WSI, Fig. 5) was impressively high in F. ornus when compared to that estimated for the other two species (in July and September, WSI in F. ornus was about twice higher than that recorded for $C$. coggygria). Because the three species studied are deciduous and most trees in the study area initiate the processes leading to leaf senescence in late summer already [29], the lower leaf water status recorded in September with respect to May (and July) may be interpreted as the expression of the beginning of leaf senescence that has been reported to imply the loss of 
Fraxinus ornus L.
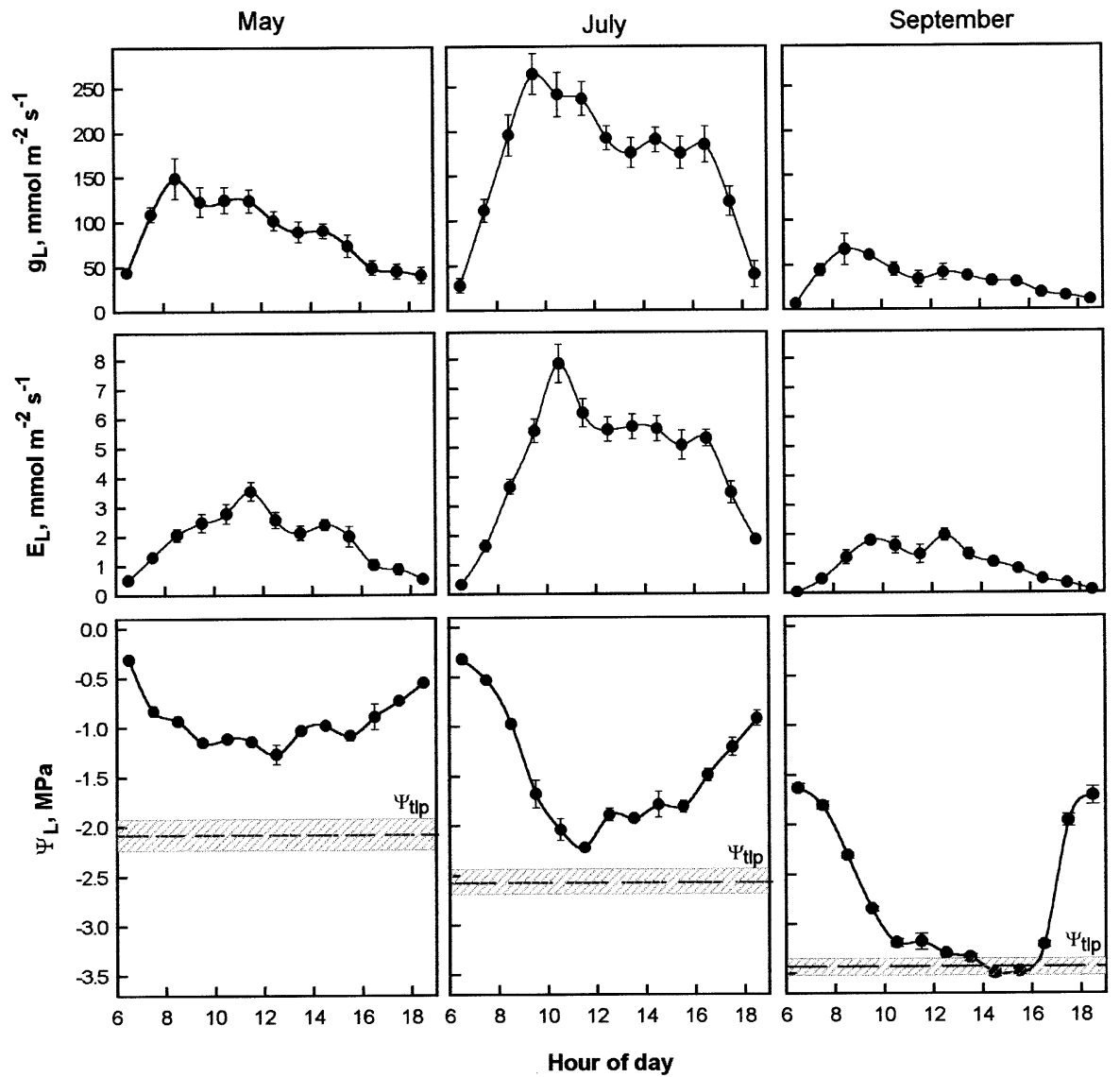

Figure 4. Diurnal time courses of leaf conductance to water vapour $\left(\mathrm{g}_{\mathrm{L}}\right)$, transpiration $\left(\mathrm{E}_{\mathrm{L}}\right)$ and water potential $\left(\Psi_{\mathrm{L}}\right)$ as measured in Fraxinus ornus $\mathrm{L}$. field-growing plants. Vertical bars are $\mathrm{SD}$ of the mean. The mean leaf water potential at the turgor loss point $\left(\Psi_{\mathrm{tlp}}\right)$ is also reported \pm SD (dashed area).

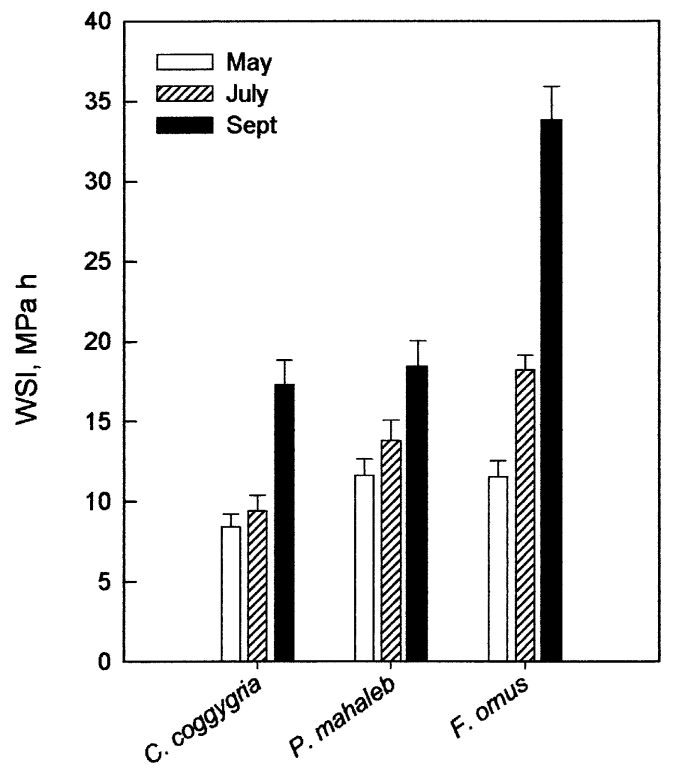

Figure 5. Integral of the diurnal time course of leaf water potential measured between predawn and sunset and here named "Water Stress Index" (WSI) calculated for the three periods under study in $\mathrm{MPa}$. Vertical bars are SD of the mean. hydraulic efficiency of petioles and stems [29]. An alternative explanation, however, is that the $\Psi_{\mathrm{L}}$ drop recorded in September in all the species studied was the consequence of the water limitation suffered by plants in August when only $20 \mathrm{~mm}$ precipitation were recorded. In fact, water limitation accompanied by high temperatures (Fig. 1) is well known to lead to xylem embolism and impair of xylem water transport [33].

The overall plant hydraulic resistances $\left(R_{\text {plant }}\right)$ were quite different in the three species studied (Fig. 6). In May, $\mathrm{R}_{\text {plant }}$ of $F$. ornus was twice as much as that recorded in C. coggygria and $25 \%$ more than $\mathrm{R}_{\text {plant }}$ of $P$. mahaleb. Such differences tended to increase in July and further in September when $\mathrm{R}_{\text {plant }}$ of $F$. ornus was 2.2 times more than that of $C$. coggygria and $58 \%$ more than that recorded in $P$. mahaleb. This suggests that differences in $\mathrm{R}_{\text {plant }}$ among species are dependent on their root, stem and leaf anatomy and they also depend on the ongoing functional losses by plant organs in terms of water transport efficiency. The decrease of $\mathrm{R}_{\text {plant }}$ recorded in July with respect to May in all the three species studied, was more due to the proportional decrease in $\mathrm{R}_{\text {shoot }}$ than to changes in $\mathrm{R}_{\text {root }}$ which changed not much (Fig. 6). In principle, $\mathrm{R}_{\text {shoot }}$ consists of the two serial components represented by stem and leaves i.e. $R_{\text {shoot }}=R_{\text {stem }}+R_{\text {leaf }}$. The hydraulic resistance of a stem can be expected to decrease as a consequence of cambial 


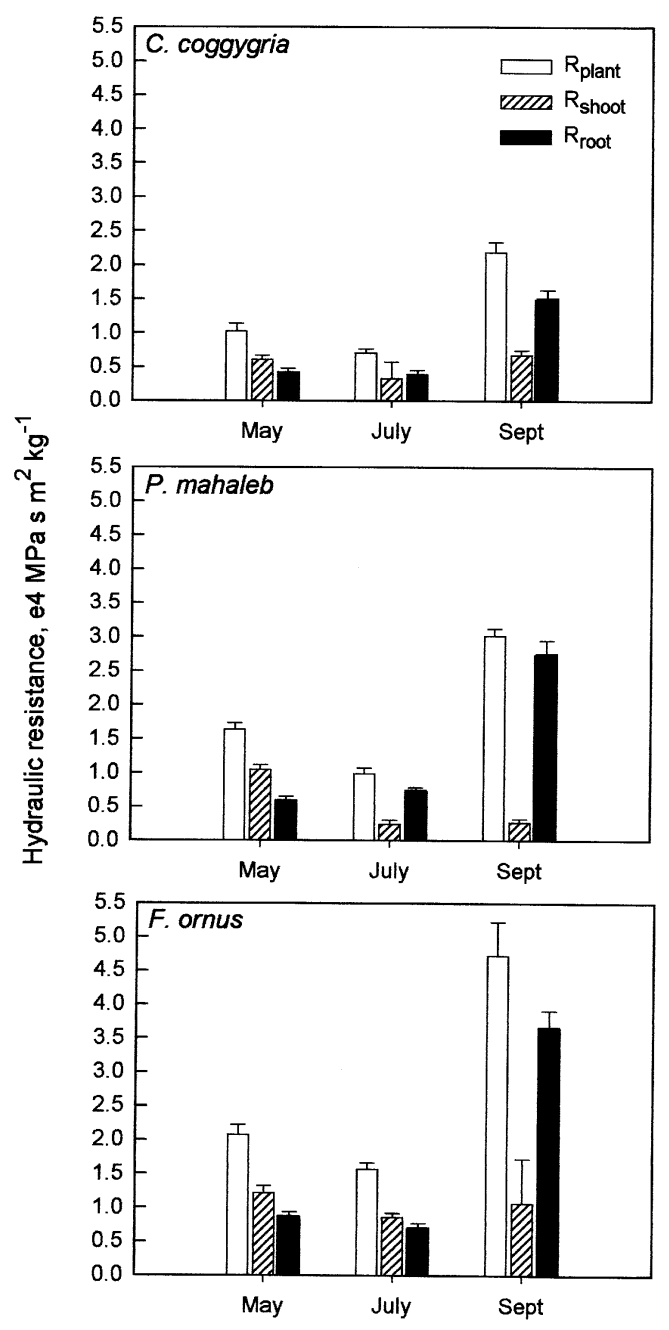

Figure 6. Hydraulic resistance $(\mathrm{R})$ of whole plants $\left(\mathrm{R}_{\text {plant }}\right.$, white columns), shoots $\left(\mathrm{R}_{\text {shoot }}\right.$, dashed columns) and roots $\left(\mathrm{R}_{\text {root }}\right.$, black columns) measured in the three periods and species under study. Vertical bars are SD of the mean.

activity leading to the new production of wide conduits that contribute most to the flow [44] and, hence, to hydraulic conductance. In our opinion, the lower $\mathrm{R}_{\text {shoot }}$ recorded in July with respect to May can be interpreted as due to new xylem conduits produced between the end of May and July corresponding to the rhythm of stem growth reported by Barnett [2] and Evert [7]. Previous studies by some of us had provided evidence that loss of hydraulic conductance (PLC) of stems of some both deciduous and evergreen trees in Friuli Venezia Giulia was typically high in the winter, persisted partly in May and was recovered only in July. As an example, PLC measured in Quercus pubescens Willd. was as high as about $70 \%$ in May and dropped to $40 \%$ in July [18]. In Quercus ilex L., PLC was about $35 \%$ in May and $10 \%$ in July [20].

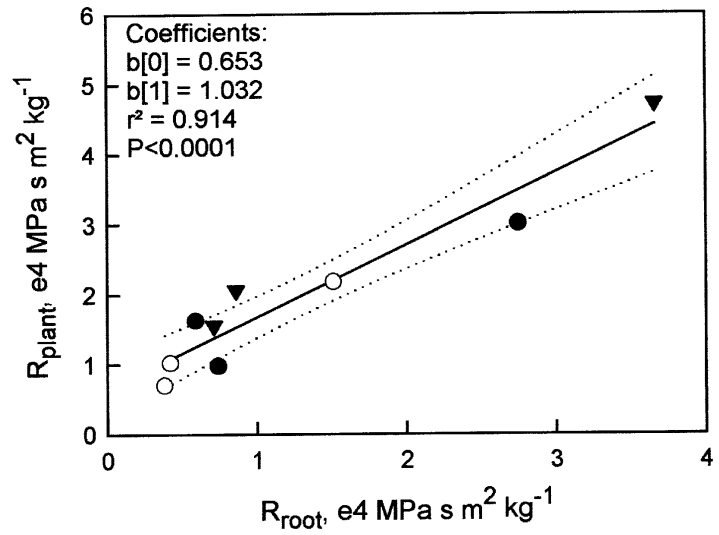

Figure 7. Relationship between the hydraulic resistance of whole plants $\left(\mathrm{R}_{\text {plant }}\right)$ and of roots $\left(\mathrm{R}_{\text {root }}\right)$. Different symbols indicate different species: Cotinus coggygria (open circles), Prunus mahaleb (solid circles), Fraxinus ornus (solid triangles). The centre solid line is the linear regression and the curved dotted lines are 95\% confidence intervals. The coefficients of the straight line are reported together with the regression coefficient $\left(\mathrm{r}^{2}\right)$ and the $\mathrm{P}$ value (Pearson Product Moment Correlation).

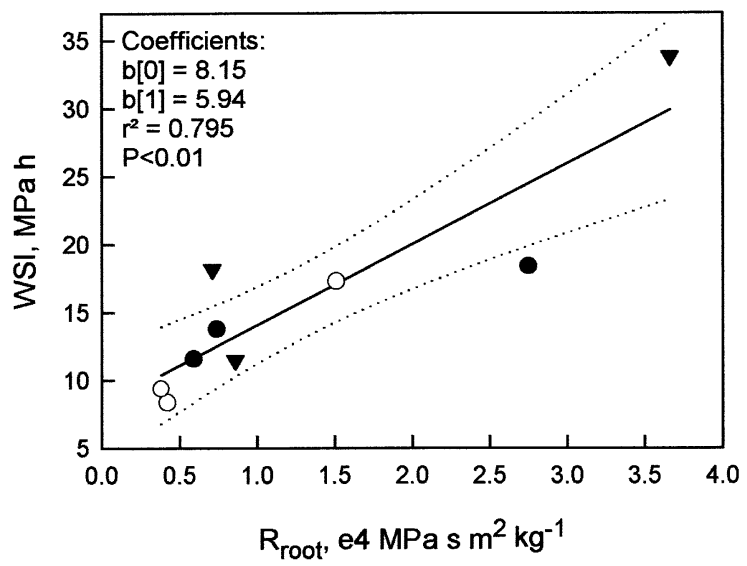

Figure 8. Relationship between the integral of the diurnal time course of leaf water potential measured between predawn and sunset, here named "Water Stress Index" (WSI) and hydraulic resistance of roots $\left(\mathrm{R}_{\text {root }}\right)$. Different symbols indicate different species (see Fig. 7). The centre solid line is the linear regression and the curved dotted lines are 95\% confidence intervals. The coefficients of the straight line are reported together with the regression coefficient $\left(\mathrm{r}^{2}\right)$ and the $\mathrm{P}$ value (Pearson Product Moment Correlation).

The noticeable increase in $\mathrm{R}_{\text {plant }}$ recorded in September for the three species under study was mostly due to $R_{\text {root }}$ that represented 70 to $90 \%$ of $R_{\text {plant }}$. Several studies have reported consistent increases in $R_{\text {root }}$ as a consequence of water stress $[5,12,23]$ stimulating the new formation of an endoderm-like multilayer of suberized cells interrupting the hydraulic continuity between soil and the root stele [36]. The impressive increase in $\mathrm{R}_{\text {root }}$ in September provides, in our opinion, a good although circumstantial explanation for the significant 
increase in WSI recorded in all the species studied, in the same month with respect to May as well as that recorded in F. ornus in July, already. Because $\mathrm{R}_{\text {root }}$ as derived on the basis of equation 6 includes the resistance of the soil-to-root pathway, it is possible that the measured $\mathrm{R}_{\text {root }}$ was due to the increase of $\mathrm{R}_{\text {soil }}$. In turn, $\mathrm{R}_{\text {soil }}$ is negligible when soil water content and $\Psi_{\text {soil }}$ are high. In our case, however, $\Psi_{\text {soil }}$ as estimated on the basis of $\Psi_{\text {pd }}$ was always below $-0.3 \mathrm{MPa}$ and as low as $-1.6 \mathrm{MPa}$ for $F$. ornus in September. This suggests that $\mathrm{R}_{\text {soil }}$ was not constant for the three species and for the three study periods. The differences recorded between species in terms of $\Psi_{\text {pd }}$ also suggest that contrasting behaviors between species might be due to different rooting patterns. However, this is only a tentative explanation because we do not have any information about the rooting depth of the species studied. It has to be taken into account that this important aspect of plant adaptation is difficult to assess because of the extensive outcropping rocks typical of Karstic soils.

Over the entire study period, the whole-plant hydraulic resistance appeared to be strongly related to $\mathrm{R}_{\text {root }}$ (Fig. 7). The close correlation between the two, confirms the root as an organ highly sensitive to changes in environmental factors like temperature and water availability as well as to plant growth rhythms. This is in accordance with several recent studies attributing to roots a major role in determining the whole-plant water balance $[6,23,35]$. In our case, in fact, the diurnal drop in $\Psi_{\mathrm{L}}$ was related to $\mathrm{R}_{\text {root }}$ with a close correlation between the two variables. In this view, hydraulic measurements can significantly implement measurements of classic water relation parameters like $\Psi_{\mathrm{L}}, \mathrm{RWC}$ and others and provide a more extensive understanding of their short-term and longterm changes.

The typical dynamic sequence of encroachment of abandoned grazing areas of the Karstic region [see above and $9,10,24]$ is in accordance with stress resistance strategies of the three species under study. In this regard, $C$. coggygria behaved like a drought resistant species combining high leaf gas exchange with rather low $\Psi_{\mathrm{L}}$ changes both in the spring and midsummer (Figs. 1 and 5). This was likely to be the result of constantly low $\mathrm{R}_{\text {root' }}$ 's (less than $0.5 \times 10^{4} \mathrm{MPa} \mathrm{s} \mathrm{m}^{2} \mathrm{~kg}^{-1}$ ) that allowed efficient water absorption and transport to leaves. Such highly efficient plant hydraulics might provide an explanation, in our opinion, of the rapid expansion of this species into abandoned degraded areas. We are aware that hydraulic architecture is only one of the factors which confer competitivity to pioneer species. Differences in height, leaf arrangement, crown shape, carbon allocation to roots versus leaves or root development, all are known to affect plant growth rate with respect to competitors. These factors were not taken into account in the present study, so our interpretation of the adaptive advantage of efficient plant hydraulics has to be taken as tentative. The significantly higher (about double) $\mathrm{R}_{\text {root }}$ and $\mathrm{R}_{\text {shoot }}$ recorded in $F$. ornus both in May and in July (Fig. 4) caused leaves of this species to approach turgor loss point during the warm period i.e. to make the species less competitive than $C$. coggygria (and $P$. mahaleb) for water and nutrient availability. The major vulnerability to water stress exhibited by $F$. ornus with respect to the other two species helps to explain why $F$. ornus expands into abandoned areas only border on newly encroached areas [24] where competition with other species is less critical and microclimatic factors are more favorable.

In conclusion, we feel that a more complete view of plant adaptation to the environment can emerge from a hydraulic description of plant organs which also allows to better interpret future possible trends in the restoration of degraded areas.

Acknowledgements: The present study was funded by Italian Ministry for University and for Scientific and Technological Research, in the frame of the National Project "Biodiversità e processi di recupero della vegetazione nelle aree marginali" (MURST Cofin 1998). We are grateful to Dr Fabio Raimondo for assistance during field measurements.

\section{REFERENCES}

[1] Abramo E., Michelutti G., Guida ai suoli forestali del FriuliVenezia Giulia, Arti Grafiche Friulane, Udine, 1998.

[2] Barnett J.R., Reactivation of the cambium in Aesculus hippocastanum L. A transmission electron microscope study, Ann. Bot. 70 (1992) 169-177.

[3] Canny M.J., Vessel contents during transpiration - embolisms and refilling, Am. J. Bot. 84 (1997) 1223-1230.

[4] Cruz R.T., Jordan W.R., Drew M.C., Structural changes and associated reduction of hydraulic conductance in roots of Sorghum bicolor $\mathrm{L}$. following exposure to water deficit, Plant Physiol. 99 (1992) 203-212.

[5] Dubrovsky J.G., North G.B., Nobel P.S., Root growth, developmental changes in the apex, and hydraulic conductivity for Opuntia ficus-indica during drought, New Phytol. 138 (1998) 75-82.

[6] Else M.A., Coupland D., Dutton L., Jackson M.B., Decreased root hydraulic conductivity reduces leaf water potential, initiates stomatal closure and slows leaf expansion in flooded plants of castor oil (Ricinus communis) despite diminished delivery of ABA from the roots to shoots in xylem sap, Physiol. Plant. 111 (2001) 46-54.

[7] Evert R.F., The cambium and seasonal development of the phloem in Pyrus malus, Am. J. Bot. 50 (1963) 149-159.

[8] Facette M.R., McCully M.E., Shane M.W., Canny M.J., Measurements of the time to refill embolized vessels, Plant Physiol. Biochem. 39 (2001) 59-66.

[9] Favretto D., Poldini L., Extinction time of a sample of Karst pastures due to encroachment, Ecol. Model. 33 (1985) 85-88.

[10] Feoli E., Feoli-Chiapella L., Ganis P., Sorge A., Spatial pattern analysis of abandoned grasslands of the Karst region by Trieste and Gorizia, Studia Geobot. 1 (1980) 213-221.

[11] Kavanagh K.L., Bond B.J., Aitken S.N., Gartner B.L., Knowe S., Shoot and root vulnerability to xylem cavitation in four populations of Douglas-fir seedlings, Tree Physiol. 19 (1999) 31-37.

[12] Lo Gullo M.A., Nardini A., Salleo S., Tyree M.T., Changes in root hydraulic conductance $\left(\mathrm{K}_{\mathrm{R}}\right)$ of Olea oleaster seedlings following drought stress and irrigation, New Phytol. 140 (1998) 25-31.

[13] Lo Gullo M.A., Salleo S., Different strategies of drought resistance in three Mediterranean sclerophyllous trees growing in the same environmental conditions, New Phytol. 108 (1988) 267-276.

[14] Magnani F., Borghetti M., Interpretation of seasonal changes of xylem embolism and plant hydraulic resistance in Fagus sylvatica, Plant Cell Environ. 18 (1995) 689-696.

[15] Mishio M., Yokoi Y., A model for estimation of water flow resistance in soil-leaf pathway under dynamic conditions, J. Exp. Bot. 42 (1991) 541-546.

[16] Nardini A., Ghirardelli L., Salleo S., Vulnerability to freeze stress of seedlings of Quercus ilex L.: an ecological interpretation, Ann. Sci. For. 55 (1998) 553-565. 
[17] Nardini A., Lo Gullo M.A., Salleo S., Competitive strategies for water availability in two Mediterranean Quercus species, Plant Cell Environ. 22 (1999) 109-116.

[18] Nardini A., Pitt F., Drought resistance of Quercus pubescens as a function of root hydraulic conductance, xylem embolism and hydraulic architecture, New Phytol. 143 (1999) 485-493.

[19] Nardini A., Salleo S., Limitation of stomatal conductance by hydraulic traits: sensing or preventing xylem cavitation? Trees 15 (2000) 14-24.

[20] Nardini A., Salleo S., Lo Gullo M.A., Pitt F., Different responses to drought and freeze stress of Quercus ilex L. growing along a latitudinal gradient, Plant Ecol. 148 (2000) 139-147.

[21] Nardini A., Tyree M.T., Root and shoot hydraulic conductance of seven Quercus species, Ann. For. Sci. 56 (1999) 371-377.

[22] Nardini A., Tyree M.T., Salleo S., Xylem cavitation in the leaf of Prunus laurocerasus L. and its impact on leaf hydraulics, Plant Physiol. 125 (2001) 1700-1709.

[23] North G.B., Nobel P.S., Drought-induced changes in hydraulic conductivity and structure in roots of Ferocactus acanthodes and Opuntia ficus-indica, New Phytol. 120 (1992) 9-19.

[24] Poldini L., La vegetazione del Carso isontino e triestino, Lint, Trieste, 1989.

[25] Prior L.D., Eamus D., Seasonal changes in hydraulic conductance, xylem embolism and leaf area in Eucalyptus tetrodonta and Eucalytpus miniata saplings in a north Australian savanna, Plant Cell Environ. 23 (2000) 955-965.

[26] Richter H., Water relations of plants in the field: some comments on the measurement of selected parameters, J. Exp. Bot. 48 (1997) $1-7$.

[27] Salleo S., Water relations parameters of two Sicilian species of Senecio (Groundsel) measured by the pressure bomb, New Phytol. 95 (1983) 179-188.

[28] Salleo S., Lo Gullo M.A., Raimondo F., Nardini A., Vulnerability to cavitation of leaf minor veins: any impact on leaf gas exchange? Plant Cell Environ. 24 (2001) 851-859.

[29] Salleo S., Nardini A., Lo Gullo M.A., Ghirardelli L.A., Changes in stem and leaf hydraulics preceding leaf shedding in Castanea sativa L., Biol. Plant. 45 (2002) 227-234.

[30] Salleo S., Nardini A., Pitt F., Lo Gullo M.A., Xylem cavitation and hydraulic control of stomatal conductance in Laurel (Laurus nobilis L.), Plant Cell Environ. 23 (2000) 71-79.

[31] Sperry J.S., Adler F.R., Campbell G.S., Comstock J.P., Limitation of plant water use by rhizosphere and xylem conductance: results from a model, Plant Cell Environ. 21 (1998) 347-359.
[32] Sperry J.S., Alder N.N., Eastlack S.E., The effect of reduced hydraulic conductance on stomatal conductance and xylem cavitation, J. Exp. Bot. 44 (1993) 1075-1082.

[33] Sperry J.S., Ikeda T., Xylem cavitation in roots and stems of Douglas-fir and white fir, Tree Physiol. 17 (1997) 275-280.

[34] Sperry J.S., Tyree M.T., Mechanism of water stress-induced xylem embolism, Plant Physiol. 88 (1988) 581-587.

[35] Steudle E., Water uptake by plant roots: an integration of views, Plant Soil 226 (2000) 45-56.

[36] Steudle E., Peterson C.A., How does water get through roots? J. Exp. Bot. 49 (1998) 775-788.

[37] Tyree M.T., Ewers F.W., The hydraulic architecture of trees and other woody plants, New Phytol. 119 (1991) 345-360.

[38] Tyree M.T., Hammel H.T., The measurement of the turgor pressure and water relations of plants by the pressure-bomb technique, J. Exp. Bot. 23 (1972) 267-282.

[39] Tyree M.T., Salleo S., Nardini A., Lo Gullo M.A., Mosca R., Refilling of embolized vessels in young stems of laurel: do we need a new paradigm? Plant Physiol. 120 (1999) 11-21.

[40] Tyree M.T., Sinclair B., Lu P., Granier A., Whole shoot hydraulic resistance in Quercus species measured with a new high-pressure flowmeter, Ann. Sci. For. 50 (1993) 417-423.

[41] Tyree M.T., Sperry J.S., Vulnerability of xylem to cavitation and embolism, Annu. Rev. Plant Physiol. Mol. Biol. 40 (1989) 19-38.

[42] Vertovec M., Sakçali S., Ozturk M., Salleo S., Giacomich P., Feoli E., Nardini A., Diagnosing plant water status as a tool for quantifying water stress on a regional basis in Mediterranean drylands, Ann. For. Sci. 58 (2001) 113-125.

[43] Zimmermann M.H., Hydraulic architecture of some diffuse-porous trees, Can. J. Bot. 56 (1978) 2286-2295.

[44] Zimmermann M.H., Xylem structure and the ascent of sap, Springer Verlag, New York, 1983.

[45] Zimmermann M.H., Potter D., Vessel length distribution in branches, stem and roots of Acer rubrum, IAWA Bull. 3 (1982) 103-109.

[46] Zimmermann M.H., Sperry J.S., Anatomy of the palm Raphis excelsa IX. Xylem structure of the leaf insertion, J. Arnold Arbor. 46 (1983) 160-180.

[47] Zwieniecki M.J., Holbrook N.M., Diurnal variation in xylem hydraulic conductivity in white ash (Fraxinus americana L.), red maple (Acer rubrum L.) and red spruce (Picea rubens Sarg.), Plant Cell Environ. 21 (1998) 1173-1180. 